Brock Education, Vol 18, 2008

\title{
Overcoming The Obstacles: Postsecondary Education and Aboriginal Peoples
}

\author{
Jane P. Preston: University of Saskatchewan, Canada
}

\begin{abstract}
For many Aboriginal peoples, trying to acquire a postsecondary education denotes overcoming a multitude of formidable barriers. Within this paper, I discuss the nature of these obstacles, which I classify as: (a) historical; (b) educational; (c) social, economic, and geographical; (d) cultural and pedagogical; and (e) financial. Also within this article, I offer suggestions of how to surmount each of these grave challenges.
\end{abstract}

\section{Introduction}

There are a multitude of obstacles that Aboriginal peoples must overcome if they are to acquire postsecondary qualification. I classify the nature of these obstacles as: (a) historical; (b) educational; (c) social, economic, and geographical; (d) cultural and pedagogical; and (e) financial. Although overcoming these formidable barriers may seem like a daunting task, progress is being made. Advancement in postsecondary programs for Aboriginal peoples in Canada is reflected by the increasing number of Aboriginal peoples who are currently attending and completing postsecondary programs. Within this paper, I discuss the aforementioned obstacles associated with Aboriginal postsecondary education, and I describe various means for overcoming these grave challenges. A thought-provoking point to bear in mind while reading this article is although the following pages specifically address the topic of postsecondary education, much of the information and many of the suggestions are easily transferable to an array of Aboriginal educational landscapes. Within Canadian elementary schools, high schools, trade schools, colleges, and universities, a more enticing, successful learning environment can be offered to Aboriginal peoples by reflecting upon and responding to the key messages portrayed throughout this synopsis of postsecondary education for Aboriginal peoples.

\section{Historical Obstacles}

Prior to the 1960s, postsecondary education for Aboriginal peoples was almost nonexistent and, therefore, rarely discussed. Among Aboriginal peoples, the unpopularity of higher education was largely due to the fact that, historically, governmental policies used education as a way to aggressively assimilate Aboriginal peoples into mainstream Eurocentric society (Canada Millennium Scholarship Foundation, 2004; Vickers, 2002). The Royal Commission on Aboriginal Peoples (1996) acknowledged that many of the social problems presently affecting Aboriginal communities can be traced back to the debilitative experience that Aboriginal students faced while in residential schools. From mandatory religious training, to rules which forbade the use of Indigenous languages and cultures, residential schools and their oppressive form of education had devastating effects upon the Aboriginal peoples (Grant, 2004). Even today, many Aboriginal peoples regard postsecondary education as an assimilative-type of coercion; one which forces Aboriginal peoples to fit into a dominant Eurocentric culture (Friesen \& Friesen, 2005; Holmes, 2006; Royal Commission on Aboriginal Peoples, 1996).

Overcoming historical obstacles is about self-government. The Royal Commission on Aboriginal Peoples (1996) stated that where Aboriginal peoples have exercised control over their 
own education, success rates have improved. Inuit Tapiriit Kanatami (2007) concurred postsecondary programs "...must be bold, innovative, generous and all-encompassing with a focus on successful student learning rather than on the perpetuation of colonial and sometimes rigid institutionalized systems" (p. 3). A number of reports (e.g. Canada Millennium Scholarship Foundation, 2004; Holmes, 2006) confirmed that when Aboriginal peoples self-manage and develop their own Indigenous-focused curricula, enrollment numbers, retention rates, and overall student satisfaction within these programs increase.

To empower the autonomy and voice of Aboriginal peoples, postsecondary educational policies need to welcome Aboriginal leaders, Elders, instructors, staff, students, and community members as integral members of governing, planning, and decision-making committees. On behalf of the Inuit culture, Inuit Tapiriit Kanatami (2007) stipulated that programs need to be developed, delivered, and administered within Inuit communities by Inuit educators. There are additional means of promoting Aboriginal self-determination within postsecondary programs. The availability of Aboriginal counselors help students cope with the constant discrimination and marginalization faced by many Aboriginal people. The presence of resident Elders assists in bringing Aboriginal philosophy and traditional values to the institution. Adequate library resources focusing on Aboriginal issues promote the academic and cultural needs of Aboriginal peoples. Aboriginal gathering centers, which honor guest speakers, social celebrations, and Aboriginal ceremonies need to be readily available for instructors, students, and the schoolcommunity.

\section{Educational Obstacles}

In order for Aboriginal people to enroll in postsecondary programs, they need to complete high school. Of First Nations and Inuit peoples between the ages of 15 and 24, 72.4\% of males and $66.5 \%$ of females have less than a high school certificate (Hull, 2005). Many Aboriginal children live in small remote communities where the quality of education is often below that received within larger communities. Numerous studies have indicated that the education Aboriginal peoples received in elementary and high schools did not adequately prepare them for a future in postsecondary education (Hull, Phillips, Polyzoi, 1995; Hull, 2000; Nora \& Cabera , 1996; Wells, 1997). Lack of study skills, program requirements, and academic knowledge, especially in the areas of Mathematics and Science, also prevent students from entering postsecondary education (Hardes, 2006).

Lack of career counseling and educational role models are other barriers to Aboriginal postsecondary education. Many of the Aboriginal students attending postsecondary institutes are among the first in their families to leave their homes in pursuit of higher education. Often these first-generation, postsecondary students lack mentors to help them with postsecondary educational transitions (Hardes, 2006). Within many remote Aboriginal communities, postsecondary career promotion and information is practically nonexistent (Holmes, 2006). Across Canada, there is a substantial need for more Aboriginal instructors and staff to be employed by universities, colleges, and other postsecondary institutions (Hardes, 2006). In the same realm, Aboriginal faculty members are under-represented in high-profile administrative jobs (Holmes, 2006).

One way to surmount these educational barriers is to acknowledge the diverse knowledge many Aboriginal peoples have and, accordingly, adjust postsecondary requirements. Typically, the acceptance of a student into a postsecondary program is largely dependent upon his/her high school marks (Kvale, 2007). While selection by grade percentages might appear to be neutral in regards to social class discrimination, it is not. The mainstream educational system is built 
around White-dominated, middle-class values and beliefs (Goodman, 2001), and marks attained from participation in school-related activities and assessment procedures are only one dimension of learning. For this reason, admission policies within Aboriginal postsecondary institutions need to be reconsidered to incorporate the life experiences of Aboriginal peoples. As many Aboriginal peoples are experienced in the areas of hunting, fishing, and trapping (Nadasdy, 2001), the collective knowledge they may have accumulated in regards to the contour of the land, the elements of water, and the characteristics and behaviors of birds, plants, animals, and fish, for example, is not something that can be represented within the futile boundaries of a number or mark. Postsecondary acceptance which is wholly dependent upon a grade-point average captures neither the intellect nor the experience of many Aboriginal students.

A simple, but relevant, response to the White-dominated enrollment policies of many postsecondary institutions is to adjust admission requirements such that admission credentials include variegated aspects of Aboriginal knowledge. In turn, for Aboriginal students who are accepted into postsecondary programs, academic supports must be available, if and when needed. For instance, transition-year programs would assist Aboriginal peoples who may not meet general admission standards (Association of Universities and Colleges of Canada, n.d.). The provision of tutors and supplementary workshops after classes facilitate comprehension of content material. Reorganizing the length of programs is another way of dealing with the high academic pressure of postsecondary education. In such a case, a two-year program would be extended over three years (Holmes, 2006).

In an effort to address lack of career direction, postsecondary programs and recruitment efforts for Aboriginal peoples need to have a greater presence within elementary and high schools. In addition, when Aboriginal students arrive at postsecondary institutions, mentoring programs need to be in place to assist new Aboriginal students during their transition into this novel and often intimidating environment (Hardes, 2006). Through a variety of institutionallysponsored activities, new students can be paired with returning students. As well, as expressed above, it is equally important that postsecondary institutions welcome Elders and other Aboriginal community members to their campuses to serve as student advisors, counselors, guest lectures, and resource personnel (Holmes, 2006). Increasing the number of Aboriginal instructors needs to be a top priority among most postsecondary institutions across Canada.

\section{Social, Economic, and Geographic Obstacles}

Aboriginal peoples have long endured a host of unfair social, economic, and geographical barriers, all of which have had traumatic effects upon Aboriginal peoples and their families. Within many Aboriginal communities, housing conditions are sub-standard (Holmes, 2006), and compared to the rest of the nation, infant mortality is double (Friesen \& Friesen, 2005). Suicide rates are five to seven times higher for First Nations youth as compared to non-Aboriginal youth; among Inuit youth, suicide rates are 11 times the national average (Johal, 2007). Poverty, unemployment, poor health conditions are stark realities for many Aboriginal peoples (Friesen $\&$ Friesen, 2005). As if these horrific manifestations of inequality and discrimination are not detrimental enough to postsecondary success rates, in an attempt to access higher education, many Aboriginal peoples are forced to migrate to urban areas. When arriving in cities, Aboriginal peoples are faced with a myriad of additional challenges including housing shortages and lack of quality childcare (Friesen \& Friesen, 2005; Prokop \& MacDonald, 2004). As indicated by Holmes (2006), Aboriginal students are more likely than non-Aboriginal students to have dependent children. Obviously, being a student at college or university is far more difficult when simultaneously assuming the full-time responsibility of raising children. Bearing this point 
in mind, it is not surprising Aboriginal students who do not complete postsecondary programs state family duties and financial insecurity as the two most powerful deterrents of their success (Statistics Canada, 2007).

One way to deal with the social, economic, and geographic challenges of postsecondary education is by bringing postsecondary education to Aboriginal peoples within their communities. Human Resources and Social Development Canada (2006) explained that community-based programs, synonymous with outreach programs, have the advantage of allowing students to remain in their home communities, while simultaneously maintaining family ties and community support. Inuit Tapiriit Kanatami (2007) acknowledged the many benefits of community-based programs. For example, community-based programs: (a) increase the accessibility of postsecondary education for Aboriginal adults who have extensive family and community commitments, (b) place higher emphasis on the inclusion of cultural knowledge, (c) eliminate cultural shock often associated with moving to urban areas, (d) provide authentic work experiences, and (e) contribute to improved retention rates. A variety of colleges and universities have linked community-based programs with increased enrollments and improved completion rates for Aboriginal peoples (Friesen \& Friesen, 2005).

Undeniably, there are many challenges associated with community-based programs. For example, students enrolled in these programs have limited access to primary learner resources and have a more-limited number of course choices. Both of these challenges may easily extend a program's completion time. Increment weather and harsh roads conditions sometimes cause barriers to the delivery of face-to-face instruction, especially in northern regions of Canada. Furthermore, traveling time of college or university educators raises concerns when determining the overall workload of instructors (Human Resources and Social Development Canada, 2006). Due to such realities, wherever possible, it is important that various community-based courses be collaboratively offered by a variety of postsecondary institutions, and that credits for these courses are transferable across various institutional domains. Wherever possible, Aboriginal educators from local communities can assist in the instruction and delivery of the program. In addition, allowing free use of community facilities for the delivery of instruction is accommodating for community-based programs (Human Resources and Social Development Canada, 2006).

For Aboriginal students who are forced to move to larger areas to acquire their postsecondary education, the provision of family housing, daycare on campus, and transportation for any dependents attending elementary and high school would assist in alleviating some of the problems associated with migrating from rural and remote areas (Hardes, 2006; Prokop \& MacDonald, 2004). As well, counseling facilities, offices for Elders, and meeting rooms for Elders, guest speakers and students address some of the cultural and social needs of Aboriginal students who leave their homes in search of higher education (Association of Universities and Colleges of Canada, n.d.).

\section{Cultural and Pedagogical Obstacles}

The language, learning styles, teaching styles, communication modes, and cultural patterns that are reflected within most postsecondary institutions differ greatly from the traditional pedagogy of Aboriginal peoples. For many Aboriginal peoples, English is not their first language. In 2006, 50\% of the Inuit population reported Inuktituk as their mother tongue, while $51 \%$ of First Nations people living on a reserve conversed in their Indigenous language (Fitzpatrick, 2008). Few postsecondary institutes provide instruction in an Indigenous language (Hardes, 2006). In addition, the mainstream educational practices of many colleges and 
universities epitomize learning as an experience largely involving competitiveness, individuality, status projection, and judgment (Gorman, 1999). Conversely, Aboriginal pedagogy prioritizes learning that is acquired through cooperation, storytelling, group discussion, demonstration, modeling, and observation (Gorman, 1999; Hardes, 2006). The holistic style of Aboriginal education incorporates practical, spiritual, physical, and emotion knowledge, passed on from the Elders to the rest of the community (Hardes, 2006; Inuit Tapiriit Kanatami, 2007). The concept of assessment is also viewed differently within Western cultures as compared to Aboriginal cultures. Formative test-taking measures and teacher-focused feedback are often the predominant types of assessment strategies utilized within mainstream postsecondary education (Kvale, 2007). Conversely, as explained by Louise Legare, an instructor at the Indian Teacher Education Program at the University of Saskatchewan, the assessment of Aboriginal students incorporates a dimension of self-reflection and self-growth, which is an extremely personalized process, manifested within the spiritual, emotional, intellectual, and physical realms of each student (L. Legare, personal communication, February 4, 2008).

To overcome the cultural and pedagogical obstacles of postsecondary education for Aboriginal peoples means that Aboriginal culture, values, and educational pedagogy needs to be incorporated into program content and delivery. Successful programs are those which build upon the needs of Aboriginal peoples and their communities, and, therefore, whenever possible, course content should be connected to relevant issues reflected within local Aboriginal communities (Friesen \& Friesen, 2005). Non-Aboriginal instructors must be cognizant of the pedagogy of Aboriginal education and utilize a variety of student-focused, cooperative teaching strategies such as learning circles, storytelling, journaling, field trips, and peer tutoring (Friesen \& Friesen, 2005). Wherever possible, student participation should be voluntary (Friesen \& Friesen, 2005; Hardes, 2006). Postsecondary Aboriginal programs need to emphasize experiential learning as reflected with practicum, cooperative, or work-place experiences. Such opportunities promote hands-on learning, the practicality of learning, and the applicability of knowledge, all of which are valued by Aboriginal peoples (Hardes, 2006). As well, when trying to overcome cultural and pedagogical obstacles of First Nation and Inuit postsecondary education, the participation and presence of Elders cannot be overestimated. Elders add a rich dimension of cultural, emotional, and spiritual wisdom to any postsecondary program (Inuit Tapiriit Kanatami, 2007).

\section{Financial Obstacles}

Attending university is expensive. Despite costs, approximately $50 \%$ of all Canadian postsecondary students go through school without accumulating a significant debt (Holmes, 2006). This point is largely due to the fact that many students assume part- or full-time employment, have scholarships, and/or rely on the financial support of their families. The other half of postsecondary students who do incur debt, take out various types of loans and/or are employed (Holmes, 2006). Specifically, many Aboriginal postsecondary students encounter higher costs while assuming postsecondary education. For example, many of the Aboriginal students who move to the cities for their higher education face additional costs associated with travel, accommodation, and childcare (Holmes, 2006). Compounding these personal difficulties, many Aboriginal students do not rely on financial support from families. Although Aboriginal peoples are eligible to receive federal funding from the Post-Secondary Student Support Program (PSSSP), a number of issues must be addressed by these aspiring students before funding is secured. First, to receive this financial assistance (which is granted by Indian and Northern Affairs Canada), a prospective student must be a registered member of a band. Funding is then subject to band council approval (Indian and Northern Affairs Canada, 2000). Because of 
location, individuals living off-reserve often have additional challenges when securing finances (Holmes, 2006). Furthermore, a student who receives government support from his/her band is generally ineligible for any other federal and provincial loans (Holmes, 2006).

To make matters worse, although the number of Aboriginal students attending postsecondary institution is increasing, the number of Aboriginal students being funded is decreasing. In 1995-96, 27,183 students were funded by Indian and Northern Affairs Canada, as compared to around 25,000 in 2000-01 (Holmes, 2006). The Assembly of First Nations estimated that more than 8,000 eligible students did not get any funding during the 2000-01 school year (Holmes, 2006). For the 2007-2008 school year, the Ontario Native Education Counselling Association (2007) stated that close to 3,000 Aboriginal students were denied funding for postsecondary education. Lyle Whitefish, Vice Chief of the Federation of Saskatchewan Indian Nations, commented, "There is a wait list on every reserve of students wanting to continue on past grade 12 and [due to lack of funding] we can't accommodate them all" (Warnyca, 2008, p. 10).

In addition to the lack of available funding for students, most of the Aboriginal institutes, themselves, are insufficiently funded (Human Resources and Social Development Canada, 2006). Why is this the case? First, understanding which level of government has jurisdiction and responsibility for funding Aboriginal postsecondary education is not a clear-cut endeavor. The federal government claims that postsecondary education clearly falls under the auspices of the provincial government; the provincial government views funding arrangements as a responsibility secured within federal realms (Stonechild, 2006). As a result, many First Nation postsecondary programs are either funded inadequately or are not funded at all. In Ontario during the 2007-2008 school year, Aboriginal postsecondary institutions received as little as $\$ 1,527$ per student, as compared to an average of $\$ 9,669$ per student in mainstream colleges and universities (Ontario Native Education Counselling Association, 2007). Exacerbating these challenges, the cost of classes for Aboriginal students as compared to mainstream classes is often higher (Human Resources and Social Development Canada, 2006). The higher expenditure associated with Aboriginal classes is, in part, due to lack of Aboriginal resources and lack of infrastructure (Associate Universities and Colleges of Canada, n.d)

To successfully address these financial obstacles, the federal and provincial governments must ensure sufficient finances are available to all Aboriginal students who wish to receive postsecondary certification. As well, in an effort to meet program goals, federal and provincial governments need to provide adequate funding to Aboriginal postsecondary institutions. In order for postsecondary institutions to fully meet the specialized needs of Aboriginal students, the operational capacity of Aboriginal institutes needs to be improved. For example, increasing library resources, improving and developing infrastructure, and creating additional Aboriginalfocused curricula (Associate Universities and Colleges of Canada, n.d.) are imperative to improve the quality and success of postsecondary programs. In addition, application and funding procedures for postsecondary education are often a tedious bureaucratic task, involving layers of federal and provincial/territorial governance departments. This administrative burden must be eased for Aboriginal peoples (Assembly of First Nations, 2005). Increasing the quality and quantity of various scholarships, bursaries, and other financial aids sponsored by governments, postsecondary institutions, and community organizations can also make a huge difference to those Aboriginal students in need of extra finances.

\section{Concluding Remarks}


Between 1996 and 2006, the Aboriginal population within Canada grew six times faster than the non-Aboriginal population (Statistics Canada, 2008). While the number of Aboriginal peoples with postsecondary qualifications has increased over the past decade, the attention, energy, and finances devoted to improving postsecondary education for Aboriginal peoples need to be ranked as a higher priority among Canadian leaders. The urgency of and the benefits from endorsing postsecondary education for Aboriginal peoples is supported by additional statistical information. As compared to non-Aboriginal people, Aboriginal peoples have lower levels of postsecondary certification (Hull, 2005), higher rates of unemployment (Statistics Canada, 2005), and below average incomes (Indian and Northern Affairs Canada, 2004). Advocating increased postsecondary education for Aboriginal peoples is advocating an invigorating, fortifying future for Aboriginal peoples, their families, and their communities.

The promotion of the spiritual, emotional, physical, and academic well-being of Aboriginal peoples in Canada requires vast improvements to postsecondary education. In order for Aboriginal peoples to be able to overcome a multitude of obstacles which weaken prospects of educational success, the programs, themselves, must be specialized to conscientiously meet the needs of Aboriginal peoples. Postsecondary education and training programs need to be innovative, supportive, and empowering for Aboriginal peoples. Aboriginal self-governance in postsecondary institutes is an important component which contributes to the success of postsecondary education for Aboriginal peoples. Fortunately, progress is being made in this area as Indigenous governments and leaders continue to assert autonomy within postsecondary education. Such advancement, however, is often hampered by lack of recognized selfgovernance from federal/provincial organizations and by lack of adequate funding, both of which are critical for the promotion and sustainability of Aboriginal educational systems.

Aboriginal students who aspire to succeed in postsecondary institutes must be supported by a variety of initiatives. For example, career advice in middle school and high school, transitional supports in postsecondary institutes, the presence of Elders, Aboriginal resources, Aboriginal instructors and staff members, community-based programs, and curricula and pedagogy reflective of Aboriginal cultural beliefs and values must be prioritized initiatives within Aboriginal postsecondary education. In order to achieve these results, once again, it is vital that adequate finances be supplied to and ease of access to funding be improved for Aboriginal students and postsecondary institutes. Generous investments of time, money, and effort need to be continually and increasingly devoted to existing and new Aboriginal postsecondary programs, thereby improving the wellness and prosperity of our entire nation.

\section{Author Note}

Acknowledgement is warmly extended to the Saskatchewan Ministry of Education and the Canadian Council on Learning's Aboriginal Knowledge Center for providing support to write this article.

\section{References}

Assembly of First Nations. (2005, April). First Nations early learning and child care action plan. Retrieved July 4, 2007, from http://www.afn.ca/cmslib/general/elcc.pdf 
Association of Universities and Colleges of Canada. (n.d.). Aboriginal access to higher education. Retrieved February 6, 2008, from http://www.aucc.ca/search/index_e.html

Canada Millennium Scholarship Foundation. (2004, January). Aboriginal peoples and postsecondary education: What educators have learned. Montreal, QC: Author.

Fitzpatrick, M. (2008, January 16). Rethinking the reserve: Aboriginal language is less common as a mother tongue. National Post. Retrieved February 5, 2008, from http://www.nationalpost.com/news/canada/rethinkingthereserve/story.html?id=241003

Friesen, J., \& Friesen, V. L. (2005). First Nations in the twenty-first century: contemporary educational frontiers. Calgary, AB: Detselig Enterprises Ltd.

Goodman, D. J. (2001). Promoting diversity and social justice: Educating people from privileged groups. London: Sage.

Gorman, W. (1999). Canadian Native students and inequitable learning. Canadian Social Studies, 33(4), 114-116.

Grant, A. (2004). Finding my talk: How fourteen native women reclaimed their lives after residential school. Calgary, AB: Fifth House Ltd.

Hardes, J. (2006). Retention of Aboriginal students in postsecondary education. Alberta Counsellor, 29(1) 28-33.

Holmes, D. (2006). Redressing the balance: Canadian university programs in support of Aboriginal students. Ottawa: Association of Universities and Colleges of Canada. Retrieved February 6, 2008, from http://www.aucc.ca/search/index_e.html

Hull, J. (2000, October 17). Aboriginal post-secondary education and labour market outcomes Canada, 1996. Ottawa, ON: Minister of Indian Affairs and Northern Development.

Hull, J. (2005, June 15). Post-secondary education and labour market outcomes Canada, 2001. Ottawa: Minister of Indian Affairs and Northern Development.

Hull, J., Phillips, R., \& Polyzoi, E. (1995). Indian control and delivery of special education services to students in Band-operated schools in Manitoba. Alberta Journal of Educational Research, XLI(1), 36-62.

Human Resources and Social Development Canada. (2006). Formative evaluation of the Institute of Indigenous Government, British Columbia, March 1988. Retrieved February 1, 2007, from http://www.hrsdc.gc.ca/cgi-bin/hrsdcrhdsc/print/print.asp?Page_Url=/en/cs/sp/hrsdc/edd/reports/1998-000410/page03.shtml

Indian and Northern Affairs Canada. (2000, December). Post-secondary Education for Status Indians and Inuit. Retrieved February 8, 2008, from http://www.aincinac.gc.ca/ps/edu/ense_e.html

Indian and Northern Affairs Canada. (2004). Income. Retrieved June 24, 2008, from http://www.ainc-inac.gc.ca/pr/sts/awp8_e.html

Inuit Tapiriit Kanatami. (2007, October 9). Post-secondary cases in Inuit education: Discussion paper no. 2 for the National Inuit Education Summit. Prepared by Silta Associates.

Johal, A. (2007, December 13). Health: Native youth suicides in Canada reach crisis rates. 
Resource Center for the Rights of Indigenous People. Retrieved February 5, 2008, from http://www.galdu.org/web/index.php?odas=2430\&giella1=eng

Kvale, S. (2007). Contradictions of assessment for learning in institutions of higher learning. In D. Boud, \& N. Falchikov (Eds.). Rethinking assessment in higher education: Learning for the longer term (pp. 57-71). London, ON: Routledge Taylor \& Francis Group.

Nadasdy, P. (2001). Hunters and bureaucrats: Power, knowledge, and the restructuring of Aboriginal-state relation in southwest Yukon, Canada. Unpublished doctoral dissertation, John Hopkins University, Baltimore, ML.

Nora, A., \& Cabera, N. A. (1996). The role of perceptions of prejudice and discrimination on adjustment of minority students to college. Journal of Higher Education, 67(2), 119-48.

Ontario Native Education Counselling Association. (2007). Fact Sheet. Retrieved February 11, 2008, from http://www.oneca.com/

Prokop, S. T., \& MacDonald, L. (2004). First Nations University of Canada, Saskatoon campus housing and daycare research project, 2004. Retrieved February 2, 2008, from http://www.bridgesandfoundations.usask.ca/reports/FNUC_housinganddaycare.pdf

Royal Commission on Aboriginal People. (1996). Report of the Royal Commission on Aboriginal Peoples: Volume 3. Ottawa, ON: Minister of Supply and Services Canada.

Statistics Canada. (2005, June 13). Labour force survey: Western Canada's off-reserve Aboriginal population. The Daily. Retrieved June 24, 2008, from http://www.statcan.ca/Daily/English/050613/d050613a.htm

Statistics Canada. (2007). Selected Educational Characteristics (29), Registered Indian Status (3), Age Groups (5A), Sex (3) and Area of Residence (7) for Population 15 Years and Over, for Canada, Provinces and Territories, 2001 Census - 20\% Sample Data. Retrieved January 31, 2008, from http://cansim2.statcan.ca/cgiwin/cnsmcgi.pgm?Lang=E\&SP_Action=Result\&SP_ID=10002\&SP_TYP=60\&SP_Sort $=-2$

Statistics Canada. (2008, January 15). Aboriginal peoples in Canada in 2006: Inuit, Métis, and First Nations, 2006 Census. The Daily. Retrieved June 24, 2008, from http://www.statcan.ca/Daily/English/080115/d080115a.htm

Stonechild, B. (2006). The new buffalo: The struggle for Aboriginal post-secondary education in Canada. Winnipeg, MN: University of Manitoba Press.

Vickers, P. J. (2002). The colonial mind in post-secondary education. McGill Journal of Education, 37(2), 241-254.

Warnyca, B. (2008, February 13). Live as if you'll die tomorrow...Learn as if you'll live forever (Mahandas Karamchand Gandhi). Country Press, pp. 9-10.

Wells, R. N. Jr. (1997, September 11). The Native American experience in higher education: Turning around the cycle of failure II. The Chronicle of Higher Education. Retrieved January 31, 2008, from http://www.eric.ed.gov/ERICDocs/data/ericdocs2sq1/content_storage_01/0000019b/80/1 5/12/76.pdf 